\title{
Timing and Temperature of Physiological Decline for Creeping Bentgrass
}

\author{
John Pote', Zhaolong Wang², and Bingru Huang ${ }^{3}$ \\ Department of Plant Biology and Pathology, Rutgers University, 59 Dudley Road, New Brunswick, \\ NJ 08901
}

\begin{abstract}
AdDitional INDEX WORDs. Agrostis stolonifera, root-zone temperature, heat stress
Abstract. Knowledge of the level of soil temperatures that is detrimental for shoot and root growth for cool-season grasses may help develop heat-tolerant plants and effective management practices to improve summer performance. The objectives of this study were to determine the level and duration of high temperatures in the root zone that will induce decline for various growth and physiological parameters and to compare the responses of different physiological parameters and cultivars to high root-zone temperatures. Nine creeping bentgrass [Agrostis stolonifera L. var. palustris (Huds.) Farw.] cultivars were subjected to eight root-zone temperatures $\left(20,21,22,23,25,27,31,35^{\circ} \mathrm{C}\right)$ in water baths while exposed to a constant air temperature of $20^{\circ} \mathrm{C}$ for 54 days. Root number, dry weight, and depth, active root biomass, turf quality, leaf cytokinin content, and canopy net photosynthetic rate $\left(\mathbf{P}_{\mathrm{n}}\right)$, decreased in all nine cultivars as root-zone temperature increased from 20 to $35^{\circ} \mathrm{C}$, but the time and temperature at which the decline occurred varied for each parameter measured. $P_{n}$, cytokinin content, root number, and turf quality declined at $23,27,27$, and $35{ }^{\circ} \mathrm{C}$, respectively, after 28 days of exposure. Active root biomass, root number, root dry weight, turf quality, and rooting depth declined at $23,25,25,25$, and $35^{\circ} \mathrm{C}$, respectively, at 54 days. At a $31^{\circ} \mathrm{C}$ root-zone temperature the decline in root number, cytokinin content, and turf quality occurred at 19,37, and 47 days, respectively. The results suggest that rootzone temperatures of $23^{\circ} \mathrm{C}$ or above this level were detrimental to root activities, $P_{n}$, and overall turf growth. Root and $P_{n}$ decline at lower temperatures and earlier in the study than turf quality suggest that the disturbance of physiological activities of roots and leaves could lead to turfgrass quality decline at high root-zone temperatures.
\end{abstract}

Supraoptimal temperature is a major factor limiting shoot and root growth of cool-season plant species. Growth of creeping bentgrass, a widely used cool-season turfgrass on golf courses, often declines during extended periods of supraoptimal temperatures. The optimal temperature for the growth of cool-season grass is broadly ranged from 18 to $24^{\circ} \mathrm{C}$ for shoot growth and 10 to $18{ }^{\circ} \mathrm{C}$ for root growth (Beard, 1973). Previous research has determined that high soil temperature was more detrimental than high air temperature in causing growth and physiological inhibition of shoots and roots in creeping bentgrass (Huang and Gao, 2000; Xu and Huang, 2000a, 2000b, 2001b) and other species (Kuroyanagi and Paulsen, 1988; Li et al., 1994; Todorovic et al., 1999). However, the critical level of supraoptimal root-zone temperatures and the duration of high-temperature stress causing physiological decline in creeping bentgrass have not been determined. Exact determination of injurious temperature levels could provide information for predicting timing and severity of physiological damages, which would help turfgrass managers to develop effective cultural practices to prevent decline of turfgrass stands during summer months.

Heat stress damage to plants involves changes of various physiological factors. The first visual signs of heat injury in turfgrasses include loss of turf color or leaf senescence and a decline in shoot density, which is often visually perceived as turf quality. Visual turf quality is the most widely used parameter to monitor turf performance in field and controlled environment studies (Bonos and Murphy, 1999; Jiang and Huang, 2000; Xu and Huang, 2000b, 2001a), although it may not provide the most information with respect to overall plant vigor. Photosynthesis is among the most sensitive physiological processes to increasing

Received for publication 3 Feb. 2006. Accepted for publication 2 May 2006. ${ }^{1}$ Graduate Student.

${ }^{2}$ Postdoctoral Research Associate

3Professor and corresponding author (huang@aesop.rutgers.edu). temperatures (Crafts-Brandner and Salvucci, 2000b). Net photosynthetic rate $\left(\mathrm{P}_{\mathrm{n}}\right)$ decreases as temperature increases above $30{ }^{\circ} \mathrm{C}$ in many cool-season plant species including turfgrasses (Al-Khatib and Paulsen, 1999; Crafts-Brandner and Salvucci, 2000b; Duff and Beard, 1974; Watschke et al., 1973; Xu and Huang, 2000a, 2000b, 2001a).

The production and viability of roots may play an important role in the adaptation of cool-season grasses to high soil temperatures. Root number, length, and mass are commonly used to evaluate root growth. Root viability, expressed as the percentage of live root tissues, has been used to monitor root activity under heat stress (Huang and Gao, 2000; Huang and Xu, 2000; Liu and Huang, 2000). Many researchers have reported that these root parameters decreased with increasing temperatures for various grass species in controlled environment experiments (Baret et al., 1992; Huang and Gao, 2000; Huang and Xu, 2000; Liu and Huang, 2000; Xu and Huang, 2000b, 2001a) and field studies (Beard and Daniel, 1966; Bonos and Murphy, 1999; Darrow, 1939; Howard and Watschke, 1991; Kuroyanagi and Paulsen, 1988; Ralston and Daniel, 1972). Cytokinins are produced mainly in roots, and may regulate shoot responses to high root-zone temperatures. Shoot growth inhibition and leaf senescence during heat stress has been associated with decreases in turfgrass cytokinin levels (Liu and Huang, 2002; Liu et al., 2002) and other plant species (Caers et al., 1985; Kuroyanagi and Paulsen, 1988; Udomprasert et al., 1995). The critical level of supraoptimal root-zone temperatures that causes detrimental effects may vary with plant parameters. However, the relative sensitivity of creeping bentgrass shoot and root parameters when subjected to high root-zone temperatures is not clear.

The objectives of this study were to 1) determine temperatures causing decline for various growth and physiological parameters of shoots and roots, 2) determine the duration of heat stress when the decline occurs for each parameter for nine creeping bentgrass cultivars, and 3) compare whether different shoot and root pa- 
rameters and cultivars vary in the level and/or duration of high root-zone temperatures.

\section{Methods and Materials}

Plant material and growth conditions. Nine creeping bentgrass cultivars were selected to represent older and newly developed cultivars ('Century', 'Crenshaw', 'L-93', 'Penn A-4', 'Penn G-6', 'Penncross', 'Putter', 'SR1020', 'Viper'). Grass sods $(\approx 0.5 \mathrm{~cm}$ thick) of these cultivars were collected from turfgrass plots established for 2 years in the Hort Farm II at Rutgers Univ. in North Brunswick, N.J. Sods were washed with water to completely remove the soil and then transplanted into clear polyethylene bags $(5 \mathrm{~cm}$ in diameter and $40 \mathrm{~cm}$ in length, with eight holes drilled at the bottom for drainage), which were filled with washed sand (particle size of 0.2 to $0.5 \mathrm{~mm}$ ) commonly used on golf greens. The polyethylene bags were placed in opaque polyvinylchloride (PVC) tubes of the same diameter and length, which were installed vertically in water baths with the lower open end exposed from the bottom of the water bath for drainage. The tubes were designed to enable plant growth to occur in well-drained sand in polyethylene tubes, while root-zone temperature was controlled at constant levels. A diagram of the water bath was presented in Wang et al. (2003).

Plants were grown in a growth chamber at $20^{\circ} \mathrm{C}$ (day/night), a photosynthetic photon flux density of $500 \mu \mathrm{mol} \cdot \mathrm{m}^{-2} \cdot \mathrm{s}^{-1}$, and a 14-h photoperiod for $60 \mathrm{~d}$ prior to the treatments. Before and during the experiment, the turf was mowed daily at $3 \mathrm{~mm}$ above the soil surface with scissors, watered daily to field capacity, and fertilized weekly with $50 \mathrm{~mL}$ of full-strength Hoagland's nutrient solution (Hoagland and Arnon, 1950).

Shoots were maintained at $20^{\circ} \mathrm{C}$ in the growth chamber. Rootzone temperatures were controlled at a constant day/night level of: 20 (control), $21,22,23,25,27,31$, and $35^{\circ} \mathrm{C}$ by keeping the entire root-zone $(40-\mathrm{cm}$-long sand column in a polyethylene bag) in different sub-compartments in a water bath while the turf canopy was kept $\approx 1.0 \mathrm{~cm}$ above the water level in the water bath. The corresponding canopy temperatures were 20, 19, 19, 20, $20,21,22$, and $23^{\circ} \mathrm{C}$. A gradient of root-zone temperatures was created in separate sub-compartments in a water bath. A heater was installed at one end of the water bath to heat water in this compartment to $38^{\circ} \mathrm{C}$. At the opposite end of the water bath, cool water $\left(20^{\circ} \mathrm{C}\right)$ was added to maintain root-zone temperature at $20^{\circ} \mathrm{C}$. Water levels were maintained at the top edge of the water bath, which was $0.5 \mathrm{~cm}$ below the top edge of PVC tubes. Rootzone temperatures were monitored weekly using thermocouples permanently placed into the root-zone at a depth of $10 \mathrm{~cm}$.

Temperature and cultivar factors were arranged in a splitplot randomized design with temperature as the main plot and cultivar as the subplot. Each root-zone temperature treatment was replicated four times using four separate water baths in a single walk-in growth chamber.

Measurements. Turfgrass quality was visually rated on a weekly basis using a 1 to 9 scale $(1=$ dead, brown turf; $9=$ green, dense, healthy turf). Plants rated 6 or greater were considered acceptable quality. The number of roots visible on the surface of the clear polyethylene bag was counted weekly in a $3 \times 3 \mathrm{~cm}$ window at 5 to $8 \mathrm{~cm}$ from the soil surface. At $28 \mathrm{~d}$ of treatment canopy net photosynthesis rate $\left(\mathrm{P}_{\mathrm{n}}\right)$ of all nine cultivars was measured individually using a portable gas exchange system (LI-6400; LI-COR, Lincoln, Nebr.) with an auxiliary chamber for canopy measurement.
Leaf cytokinin content was measured in 'PennA-4' and 'Putter' using the procedure described in Setter et al. (2001). Leaf tissue was harvested weekly and flash frozen in liquid nitrogen. Cytokinins were extracted in $80 \%(\mathrm{v} / \mathrm{v})$ methanol. Extracted cytokinins were bound to C18-silica columns (SPE-96; Supelco, Bellefonte, $\mathrm{Pa}$.) and eluted with a tri-ethylamine-acetate/methanol solution. Radiolabeled cytokinins (Amersham Co., Arlington Heights, Ill.) were added to monitor purification efficiency, which never fell below $90 \%$ efficiency. An indirect enzyme-linked immunosorbant assay (ELISA) was used to quantify three kinds of cytokinins, trans-zeatin/zeatin riboside, dihydrozeatin/dihydrozeatin riboside, and isopentenyl adenosine. The three measured cytokinins were added together for total cytokinin content. Samples from the silica columns were dried in vacuum at room temperature and dissolved in Tris buffer. ELISA plates were coated overnight at 4 ${ }^{\circ} \mathrm{C}$ with corresponding cytokinin-bovine serum albumin conjugate in carbonate buffer. Plates were washed and a monoclonal antibody for each cytokinin was added in Tris buffer, and incubated overnight at $4{ }^{\circ} \mathrm{C}$. Secondary antibody, anti-mouse IgG-alkaline phosphatase conjugate, was added in Tris buffer and incubated overnight at $4{ }^{\circ} \mathrm{C}$. Plates were washed and developed with pnitrophenyl phosphate solution for $1 \mathrm{~h}$ at room temperature. $\mathrm{A}_{405}$ was measured with a plate reader (model EL 800; Bio-Tek Instruments, Winooski, Vt.) and samples were quantified using known standards.

At $54 \mathrm{~d}$ of treatment, plants were harvested, roots were washed clean of sand, and roots were excised from shoots. Maximum rooting depth was measured with a ruler. Roots were then dried in an oven at $80^{\circ} \mathrm{C}$ for $3 \mathrm{~d}$ and root dry weight (RDW) was determined. Approximately $1.5 \mathrm{~g}$ of fresh roots from 'Putter', 'Penncross', and 'Penn A-4' were used for root viability measurements as modified from Knievel (1973). Roots were incubated in the dark for $24 \mathrm{~h}$ in $0.6 \%$ 2,3,5-triphenyltetrazolium chloride at $30^{\circ} \mathrm{C}$. Roots were rinsed with deionized water and placed in $95 \%$ ethanol at $70{ }^{\circ} \mathrm{C}$ for formazan extraction. Final volumes were adjusted and $\mathrm{A}_{490}$ was measured with a spectrophotometer (Spectronic Instruments, Rochester, N.Y.). Live roots were mixed with different proportions of autoclave-killed roots to construct a standard curve. Root viability was expressed as viable root biomass, or dry weight of viable roots per tube $\left(91.4 \mathrm{~cm}^{3}\right)$.

Effects of root-zone temperature, cultivar, duration of treatment, and their interactions were determined by the analysis of variance according to the general linear model procedure of the Statistical Analysis System (SAS Institute, Cary, N.C.). Differences among treatments, cultivars, and durations of treatments were determined by the least significance difference (LSD) test at the 0.05 probability level.

\section{Results}

Time, TEMPERATURE, AND CULTIVAR INTERACTIONS. Main effect responses for time, temperature, and cultivar were significant $(P$ $\leq 0.05$ ) for all measured parameters, except time for parameters that were only measured once. All one-way interactions were significant accept for cultivar $\times$ temperature for $P_{n}$, root dry weight, and viable root biomass. Three-way interactions were not significant for any measured parameter.

Turfgrass Quality. Turfgrass quality at $20^{\circ} \mathrm{C}$ root-zone temperature did not change for any cultivar during the entire treatment period (Fig. 1A). At $25^{\circ} \mathrm{C}$ (Fig. 1B), $31^{\circ} \mathrm{C}$ (Fig. 1C), and $35^{\circ} \mathrm{C}$ (Fig. 1D), turfgrass quality of all nine cultivars began to decline at 47,40 , and $33 \mathrm{~d}$, respectively. No cultivar differences were 
observed at $20^{\circ} \mathrm{C}$ (Fig. 1A) 'Putter', however, consistently had the lowest quality after extended periods of treatment at $25-35^{\circ} \mathrm{C}$ (Figs. 1B, 1C, 1D). Other cultivars did not show consistent differences in turf quality at different temperatures (Fig. 1A-D).

Turf quality of all nine cultivars remained constant for the first $19 \mathrm{~d}$ of exposure to all root-zone temperatures (Fig. $2 \mathrm{~A}$ and B). At 40 and $54 \mathrm{~d}$, turf quality decline occurred at $31^{\circ} \mathrm{C}$ (Fig. 2C) and $25^{\circ} \mathrm{C}$ (Fig. 2D), respectively.

ROOT CHARACTERISTICS. Root number at $5-8 \mathrm{~cm}$ in all cultivars increased over time at $20^{\circ} \mathrm{C}$ (Fig. 3A). At 25,31 , and $35^{\circ} \mathrm{C}$, root number decreased at 47,19 , and $12 \mathrm{~d}$ of treatment, respectively (Fig. 3 B and D). 'Penn A-4' had the greatest number of roots among all nine cultivars at $20^{\circ} \mathrm{C}$ (Fig. 3A) and $31^{\circ} \mathrm{C}$ (Fig. 3C). There was no consistent cultivar variation in root number at 25 and $35^{\circ} \mathrm{C}$ (Fig. $3 \mathrm{~B}$ and D).

There was no consistent change in root number with temperature at $4 \mathrm{~d}$ of treatment for any cultivar (Fig. 4A). After 19, 40, and $54 \mathrm{~d}$, root number decreased at 27,25 , and $23{ }^{\circ} \mathrm{C}$, respectively, for all cultivars (Fig. 4B-D).

Maximum rooting depth became shallower as temperature increased from 20 to $35^{\circ} \mathrm{C}$ for all cultivars (Fig. 5A). 'Penncross' had the longest rooting depth at $20-23^{\circ} \mathrm{C}$, but the shortest rooting depth at $35^{\circ} \mathrm{C}$ among all nine cultivars. There were no consistent differences in rooting depth among other cultivars at different root-zone temperatures. Decline in root dry weight was observed when soil temperature was increased to $27{ }^{\circ} \mathrm{C}$ or higher levels (Fig. 5B). At $35^{\circ} \mathrm{C}$, 'Penncross' and 'Penn G-6' had the lowest root dry weight and 'Penn A-4' had the greatest.
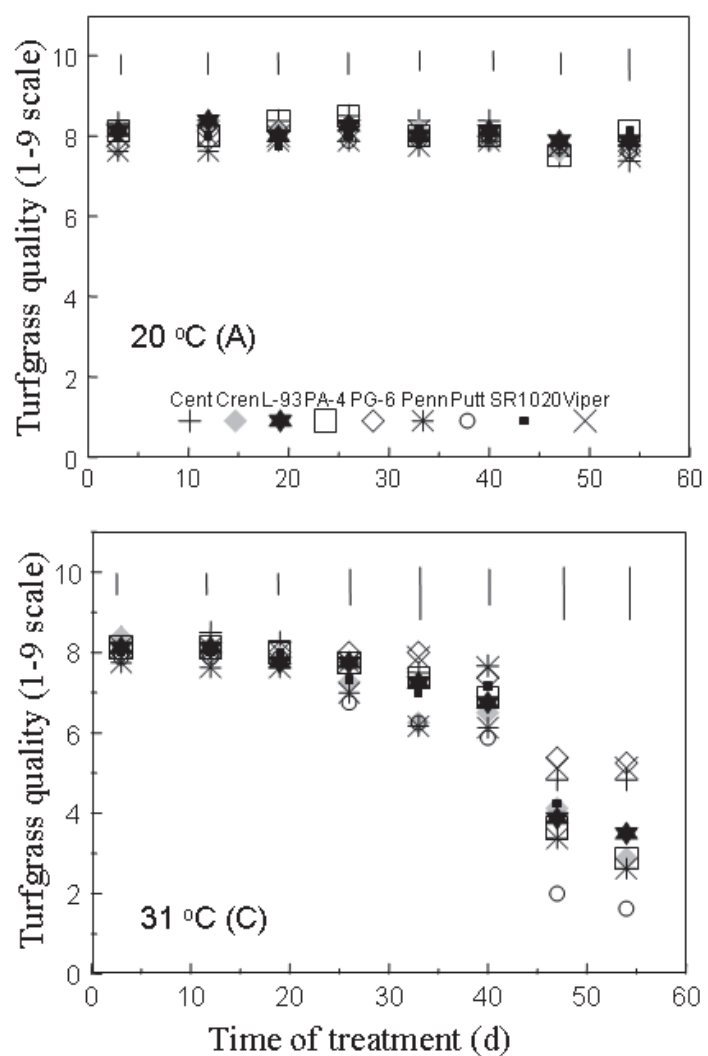

Root viability also decreased as root-zone temperatures increased from 20 to $23{ }^{\circ} \mathrm{C}$ or higher (Fig. 6). 'Penncross' had the lowest root viability among the three cultivars at root zone temperatures from 21 to $35^{\circ} \mathrm{C}$.

TEMPERATURE RESPONSE OF PHYSIOLOGICAL FACTORS. The differences in the sensitivity of leaf $P_{n}(A)$, leaf cytokinin content (B), root number $(\mathrm{C})$, and turf quality (D) to increasing root-zone temperatures at 26 to $30 \mathrm{~d}$ of treatment were compared in Fig. 7. $\mathrm{P}_{\mathrm{n}}$ for all cultivars began to decrease at root-zone temperatures as low as $23{ }^{\circ} \mathrm{C}$ at $28 \mathrm{~d}$ of treatment (Fig. 7A). $\mathrm{P}_{\mathrm{n}}$ averaged over cultivars at $35{ }^{\circ} \mathrm{C}$ was $<50 \%$ of that at $20{ }^{\circ} \mathrm{C}$. Total cytokinin content in leaves began to decrease at 31 and $27^{\circ} \mathrm{C}$ following $30 \mathrm{~d}$ of treatment for 'Penn A-4' and 'Putter', respectively (Fig. 7B). Total cytokinin level at $35^{\circ} \mathrm{C}$ was $75 \%$ of that at $20{ }^{\circ} \mathrm{C}$. Root number decreased at $27^{\circ} \mathrm{C}$ after $26 \mathrm{~d}$ of treatment for all cultivars (Fig. 7C). As temperature increased to $35^{\circ} \mathrm{C}$, root number was reduced to $<30 \%$ of the level at $20^{\circ} \mathrm{C}$. Significant decline in turf quality did not occur until temperature increased to $35^{\circ} \mathrm{C}$ at $25 \mathrm{~d}$ (Fig. 7D).

At $31{ }^{\circ} \mathrm{C}$, turfgrass quality declined at $47 \mathrm{~d}$ of treatment (Fig. 8A), leaf cytokinin content at $37 \mathrm{~d}$ (Fig. 8B), and root number at $19 \mathrm{~d}$ (Fig. 8C). At the time of decline, turf quality and root number dropped to $\approx 50 \%$ of the initial value.

\section{Discussion}

Previous research broadly defined the optimum temperature for cool-season grasses in the range of 18 to $24^{\circ} \mathrm{C}$ for shoot growth
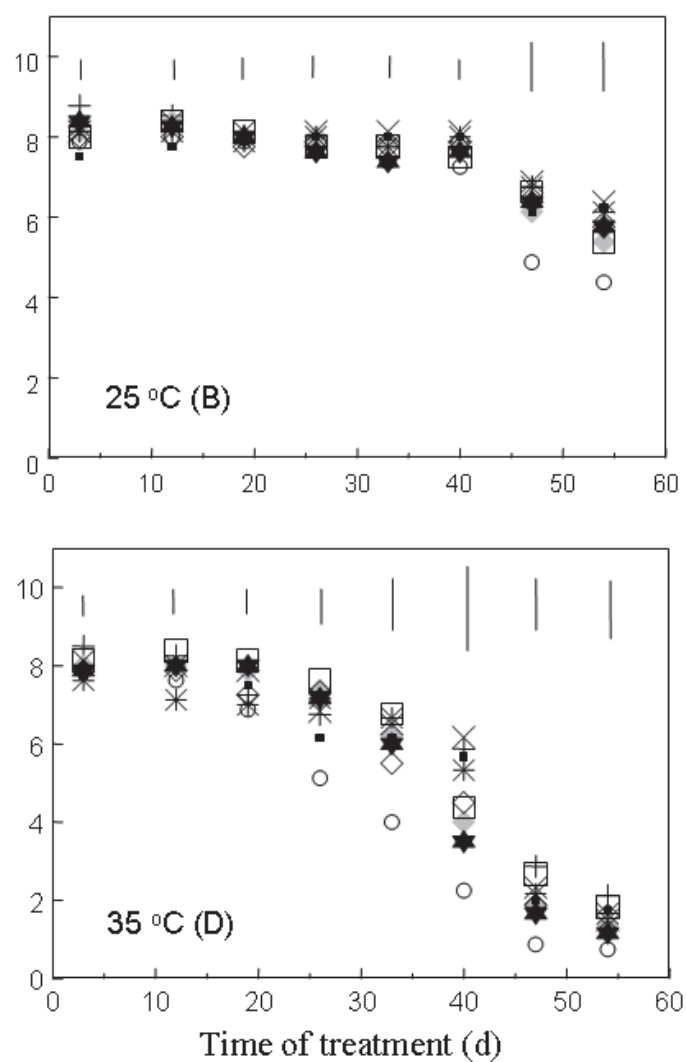

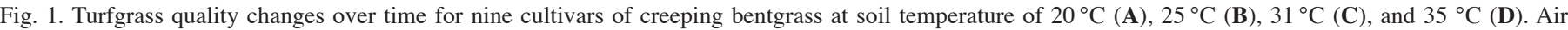

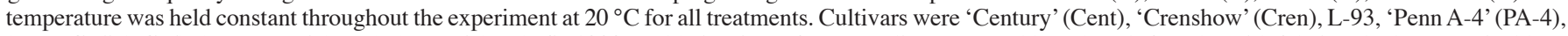

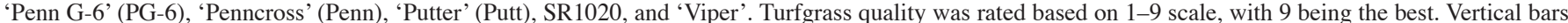

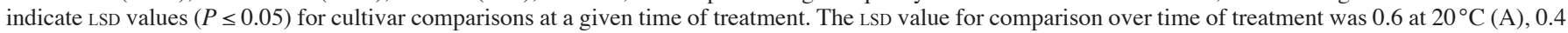
at $25^{\circ} \mathrm{C}(\mathrm{B}), 0.5$ at $31^{\circ} \mathrm{C}(\mathrm{C})$, and 0.6 at $35^{\circ} \mathrm{C}(\mathrm{D})$. 

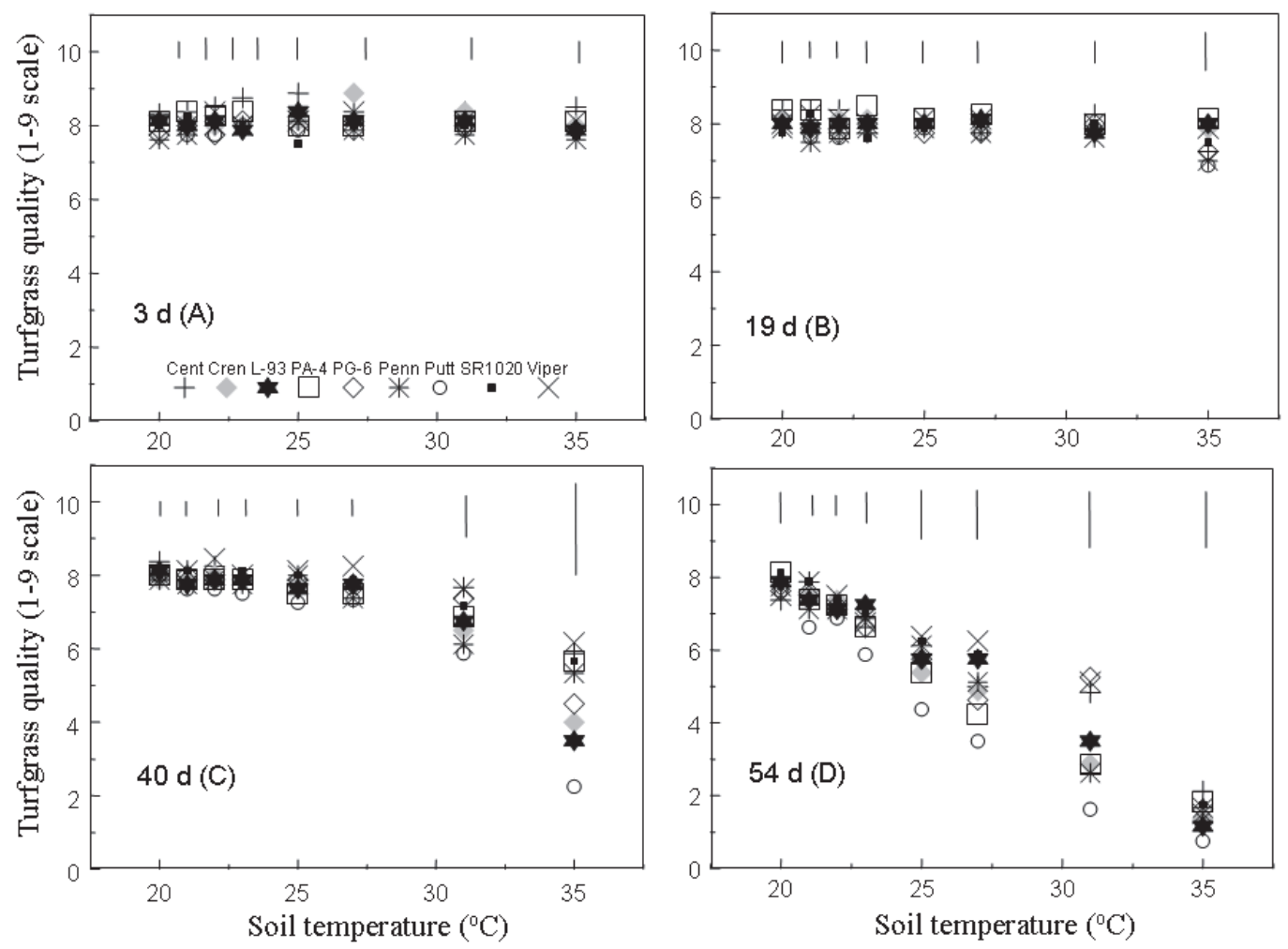

Fig. 2. Turfgrass quality changes with increasing soil temperatures for nine cultivars of creeping bentgrass at $3 \mathrm{~d}(\mathbf{A}), 19 \mathrm{~d}(\mathbf{B}), 40 \mathrm{~d}(\mathbf{C})$, and $54 \mathrm{~d}(\mathbf{D})$ of treatment. Air temperature was held constant throughout the experiment at $20^{\circ} \mathrm{C}$ for all treatments. Cultivars were 'Century' (Cent), 'Crenshow' (Cren), 'L-93', 'Penn A-4' (PA-4), 'Penn G-6' (PG-6), 'Penncross' (Penn), 'Putter' (Putt), 'SR1020', and 'Viper'. Turfgrass quality was rated based on 1-9 scale, with 9 being the best. Vertical bars indicate LSD values $(P \leq 0.05)$ for cultivar comparisons at a given soil temperature treatment. The LSD value for comparison among different temperatures was 0.3 at $3 \mathrm{~d}(\mathrm{~A}), 0.4$ at $19 \mathrm{~d}(\mathrm{~B}), 0.5$ at $40 \mathrm{~d}$, and 0.5 at $54 \mathrm{~d}(\mathrm{D})$.
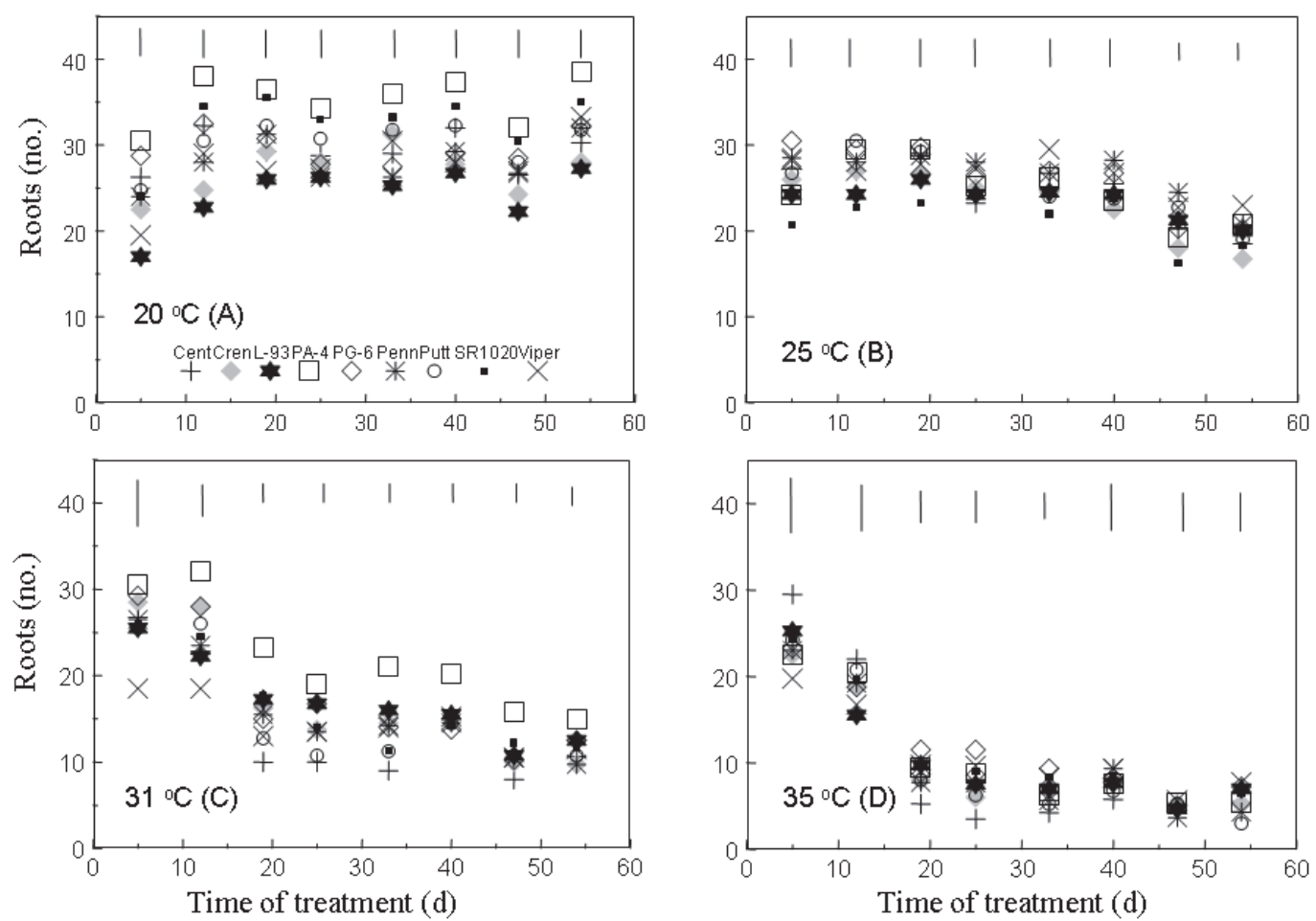

Fig. 3. Root number changes at $5-8 \mathrm{~cm}$ over time for nine cultivars of creeping bentgrass at soil temperature of $20^{\circ} \mathrm{C}(\mathbf{A}), 25^{\circ} \mathrm{C}(\mathbf{B}), 31{ }^{\circ} \mathrm{C}(\mathbf{C})$, and $35^{\circ} \mathrm{C}(\mathbf{D})$. Air temperature was held constant throughout the experiment at $20^{\circ} \mathrm{C}$ for all treatments. Cultivars were 'Century' (Cent), 'Crenshow' (Cren), 'L- 93 ', 'Penn A-4' (PA4), 'Penn G-6' (PG-6), 'Penncross' (Penn), 'Putter' (Putt), 'SR1020', and 'Viper'. Vertical bars indicate LsD values $(P \leq 0.05)$ for cultivar comparisons at a given time and comparison of all times. Vertical bars indicate LSD values $(P \leq 0.05)$ for cultivar comparisons at a given time of treatment. The LSD value for comparison over time of treatment was 3 at $20^{\circ} \mathrm{C}(\mathrm{A}), 5$ at $25^{\circ} \mathrm{C}(\mathrm{B}), 4$ at $31^{\circ} \mathrm{C}(\mathrm{C})$, and 4 at $35^{\circ} \mathrm{C}(\mathrm{D})$. 

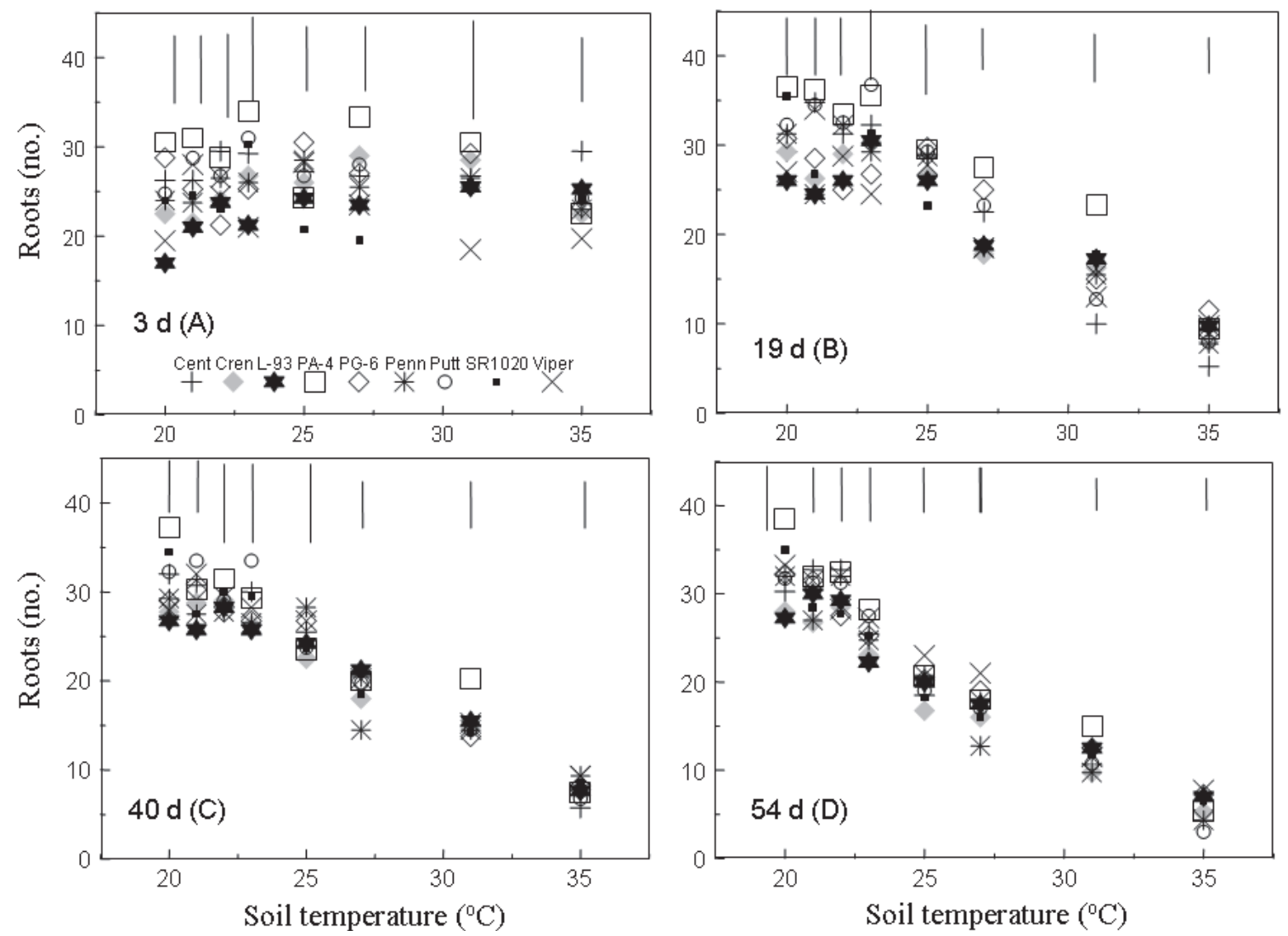

Fig. 4. Root number changes at $5-8 \mathrm{~cm}$ with increasing soil temperatures for nine cultivars of creeping bentgrass at 3 (A), 19 (B), 40 (C), and 54 (D) d. Air temperature was held constant throughout the experiment at $20^{\circ} \mathrm{C}$ for all treatments. Cultivars were 'Century' (Cent), 'Crenshow' (Cren), 'L-93', 'Penn A-4' (PA-4), 'Penn G-6' (PG-6), 'Penncross' (Penn), 'Putter' (Putt), SR1020, and 'Viper'. Vertical bars indicate LSD values $(P \leq 0.05)$ for cultivar comparisons at a given soil temperature treatment. The LSD value for comparison among different temperatures was 3 at $3 \mathrm{~d}$ (A), 2 at $19 \mathrm{~d}$ (B), 2 at $40 \mathrm{~d}$, and 2 at $54 \mathrm{~d}$ (D).

and 10 to $18^{\circ} \mathrm{C}$ for root growth, without differentiation between air and soil temperatures, growth and physiological parameters, and grass species or cultivars (Beard, 1973). The present study found that when roots only were exposed to root-zone temperatures of $20-22{ }^{\circ} \mathrm{C}$ while air temperature was at $20^{\circ} \mathrm{C}$, turf quality of all nine creeping bentgrass cultivars was maintained at a high level and root number increased during the entire treatment period (54 d), indicating that root-zone temperatures of $20-22{ }^{\circ} \mathrm{C}$ is not detrimental to either root or shoot growth of creeping bentgrass. The critical level of elevated root-zone temperatures that was detrimental for creeping bentgrass changed with treatment duration and varied with growth and physiological parameters, but did not differ among cultivars.

The level of root-zone temperatures that caused heat injuries was reduced with longer exposure duration of plants to high temperatures for all cultivars. Turf quality did not decline when root-zone temperatures increased from 20 to $35{ }^{\circ} \mathrm{C}$ within the first $19 \mathrm{~d}$ of treatment whereas the decline in turfgrass quality occurred at $25-27{ }^{\circ} \mathrm{C}$, depending on cultivar, by the end of the treatment period (54 d) (Fig. 1). Huang and Gao (2000) reported the decline in turf quality of three creeping bentgrass cultivars occurred when both air and soil temperatures increased to $30{ }^{\circ} \mathrm{C}$ for $20 \mathrm{~d}$. Root number declined at $27^{\circ} \mathrm{C}$ at $19 \mathrm{~d}$ of treatment. As the exposure duration prolonged to $54 \mathrm{~d}$, root number and viable root biomass decreased at root-zone temperatures as low as 23 ${ }^{\circ} \mathrm{C}$. The declines in root dry weight and maximum rooting depth were observed at higher temperatures than root number and viable root biomass, particularly rooting depth $\left(35^{\circ} \mathrm{C}\right)$. The lower temperature of decline for root number and viable root biomass suggests that these two parameters were more sensitive to high root-zone temperatures than root dry weight and rooting depth. This illustrates the importance of maintaining viable roots in order for plants to survive high soil temperatures.

The exposure duration to high root-zone temperature that caused physiological decline varied with plant parameters. For example, when soil temperature was raised to $31^{\circ} \mathrm{C}$, root number declined at $12 \mathrm{~d}$, cytokinin content at $30 \mathrm{~d}$, and turf quality at 40 $\mathrm{d}$ of treatment (Fig. 7). Previous research also reported earlier decline in root number than turf quality in creeping bentgrass when exposed to a high soil temperature $\left(35^{\circ} \mathrm{C}\right)(\mathrm{Xu}$ and Huang, 2000b, 2001a). Root characteristics declined earlier than shoot characteristics in other species during heat stress (Aloni et al., 1992; Du and Tachinbana, 1994; Kuroyanagi and Paulsen, 1985, 1988). Our results confirmed that root deterioration well preceded turf quality decline at high root-zone temperatures.

The comparison of responses of $P_{n}$, leaf cytokinin content, turf quality and root number to increasing root-zone temperature indicates that $P_{n}$ was most sensitive to elevated root-zone temperatures (Fig. 8). $\mathrm{P}_{\mathrm{n}}$ dropped significantly at $23^{\circ} \mathrm{C}$ following 28 $\mathrm{d}$ of treatment. Within the same time period, significant decline did not occur until $27-31^{\circ} \mathrm{C}$ for leaf cytokinin content (varied with cultivars), $27{ }^{\circ} \mathrm{C}$ for root production, and $35^{\circ} \mathrm{C}$ for turf quality. The rapid reduction in photosynthetic rate in response to elevated soil temperatures could be due to stomatal closure (Graves et al., 1989; Gur et al., 1976; Martin et al., 1989) and decreased enzyme activity, such as Rubisco (Bose et al., 1999; Xu 

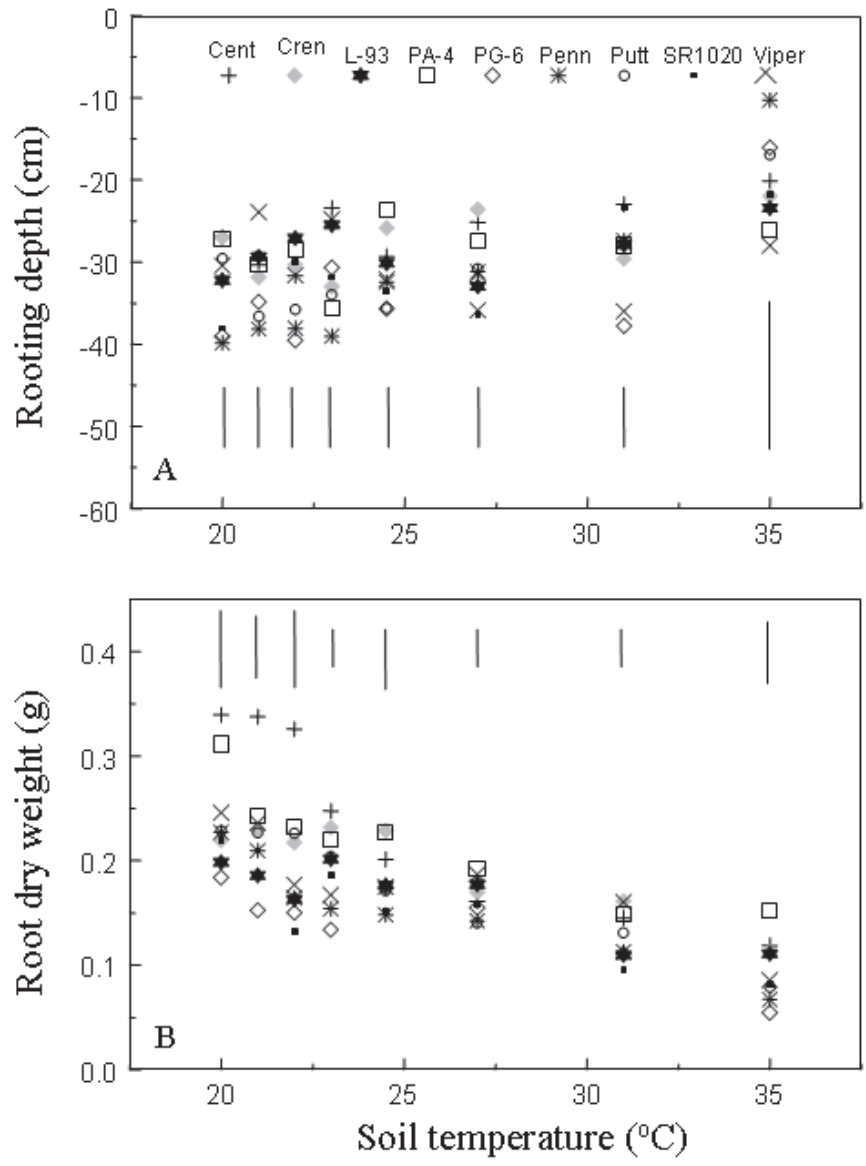

Fig. 5. Rooting depth (A) and root dry weight (B) changes with increasing soil temperatures for nine cultivars of creeping bentgrass after $54 \mathrm{~d}$. Air temperature was held constant throughout the experiment at $20^{\circ} \mathrm{C}$ for all treatments. Cultivars were 'Century'(Cent), 'Crenshow'(Cren), 'L-93', 'Penn A-4'(PA-4), 'Penn G-6 (PG-6)', 'Penncross'(Penn), 'Putter'(Putt), 'SR 1020', and 'Viper'. Vertical bars indicate LSD values $(P \leq 0.05)$ for cultivar comparisons at a given soil temperature treatment. The LSD value for comparison among different temperatures was 8 for rooting depth (A) and 0.22 for root dry weight (B). and Huang, 2001a), Rubisco activase (Law and Crafts-Brandner, 1999; Salvucci et al., 2001; Sharkey et al., 2001; Weis, 1981), and the oxygen-evolving complex (Al-Khatib and Paulsen, 1999; Downs et al., 1999; Heckathorn et al., 1999). Decreased $P_{n}$ results in decreased availability of carbohydrate, which may lead to decreased carbon allocation to roots (Todorovic et al., 1999; Udomprasert et al., 1995; Xu and Huang, 2000a; Xu et al., 2000). As root production decreased, cytokinin production in roots would decrease and this in turn limits cytokinin supply to shoots, causing leaf senescence (Kuroyanagi and Paulsen, 1988) and turf quality decline (Liu et al., 2002). Turf visual quality has been a most widely used parameter in the evaluation of turf performance. Our results suggest that physiological changes under heat stress would provide earlier signs of heat injury than visual rating of turf quality.

Cultivar variations in physiological responses were expressed mainly at higher root-zone temperatures $\left(31\right.$ and $\left.35^{\circ} \mathrm{C}\right)$, suggesting that selection of plant materials for heat tolerance should be performed at these or higher root-zone temperatures. However, there was generally lack of consistent variation in physiological responses to high root-zone temperatures among the nine cultivars examined, with few exceptions: at 31 or $35^{\circ} \mathrm{C}$, 'Putter' had lowest turf quality (Fig. $1 \mathrm{C}$ and D); 'Penn A-4' had most roots (Fig. 1C); 'Penncross' had the shallowest rooting depth (Fig. 5A).

In summary, the growth and physiological activities of both roots and shoots declined when plants were exposed to elevated root-zone temperatures above $23^{\circ} \mathrm{C}$ for extended periods of time $(54 \mathrm{~d})$. The root-zone temperature that caused the decline varied with plant parameter and stress duration, but was not affected by cultivar. The decline in $\mathrm{P}_{\mathrm{n}}$, root production and activities occurred at lower root-zone temperatures and earlier during the treatment compared to turf quality. Therefore, effective management practices, such as syringing and inserting fans, should be taken when physiological signs of heat injury occur and when soil temperature reaches the minimum detrimental levels to prevent declines in visual turf quality during summer months. These data also indicate that turfgrass quality may not be the best parameter to use for assessing heat tolerance in breeding programs.

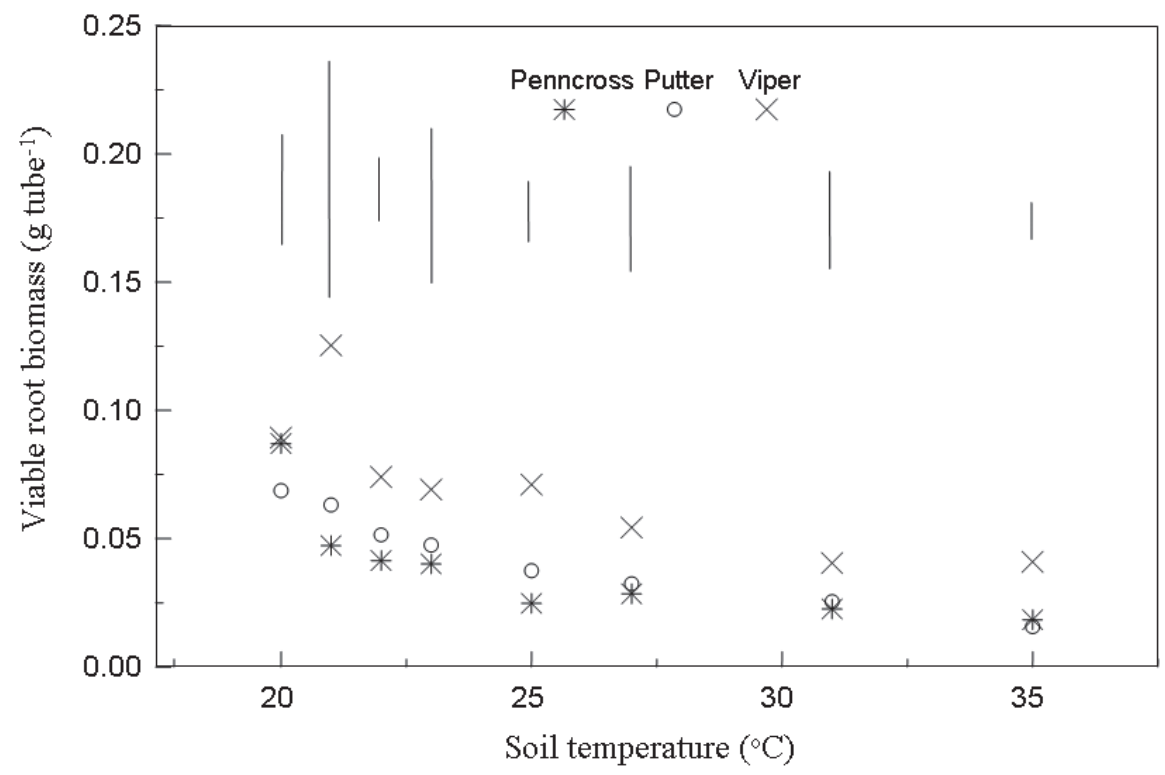

Fig. 6. Viable root biomass changes with increasing soil temperatures for three creeping bentgrass cultivars ('Penncross', 'Putter', and 'Viper') after 54 d. Air temperature was held constant throughout the experiment at $20^{\circ} \mathrm{C}$ for all treatments. Vertical bars indicate LSD values $(P \leq 0.05)$ for cultivar comparisons at a given soil temperature treatment. The LSD value for comparison among different temperatures was 0.023 . 

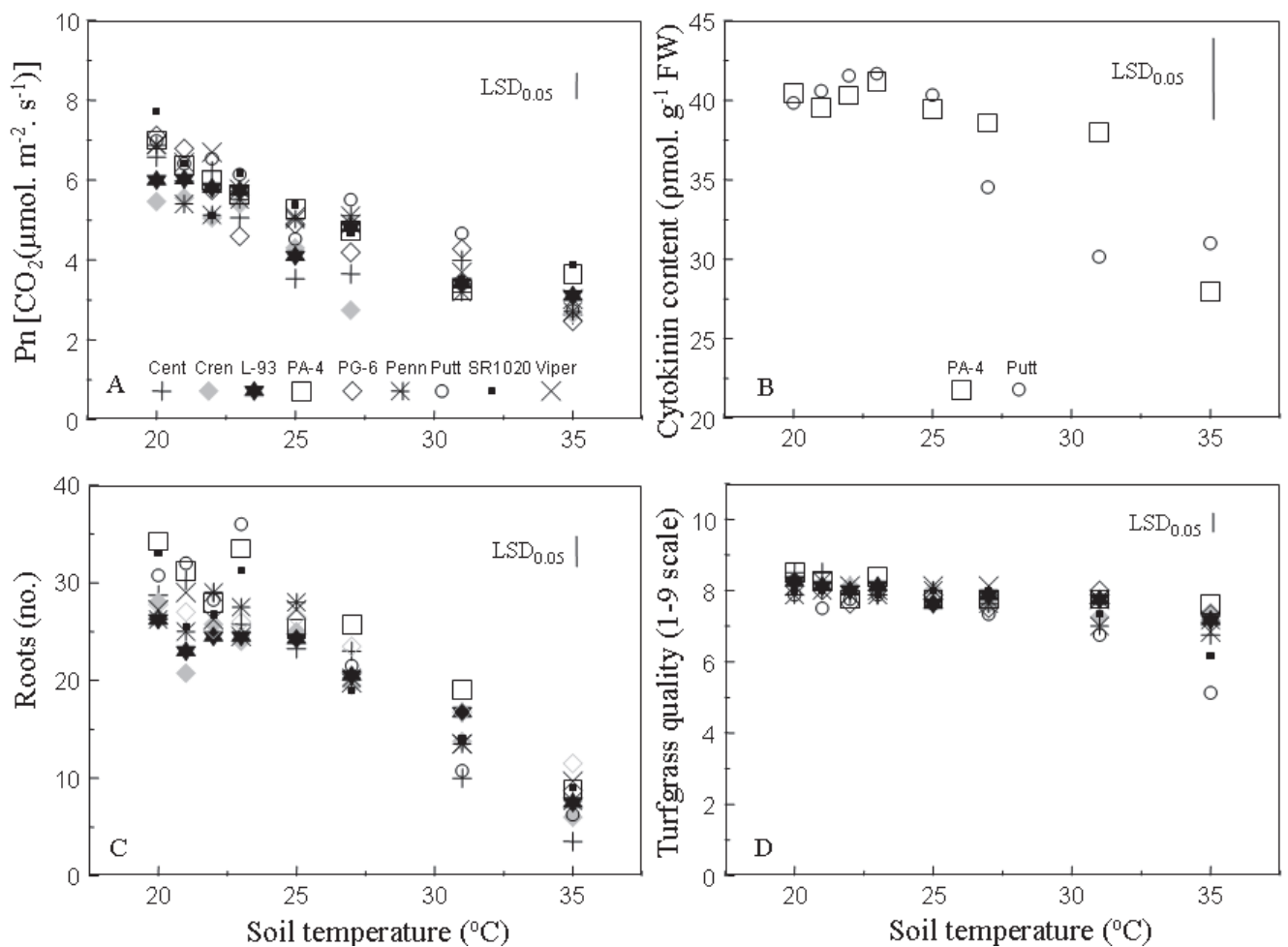

Fig. 7. Changes in canopy net photosynthetic rate $\left(P_{n}\right)(\mathbf{A})$, leaf cytokinin content $(\mathbf{B})$, root number $(\mathbf{C})$, and turfgrass quality $(\mathbf{D})$ for different creeping bentgrass cultivars with increasing soil temperatures. The four parameters were measured between $26-30 \mathrm{~d}$ of treatment. Data were from nine cultivars for $P_{n}$, root number and turf quality and two cultivars for cytokinin content. Cultivars were 'Century' (Cent), 'Crenshow' (Cren), 'L-93', 'Penn A-4' (PA-4), 'Penn G-6' (PG-6), 'Penncross' $(P e n n)$, 'Putter' (Putt), 'SR 1020', and 'Viper'. Air temperature was held constant throughout the experiment at $20^{\circ} \mathrm{C}$ for all treatments. The LSD value $(P \leq 0.05)$ for comparison over time of treatment was 0.6 for $\mathrm{P}_{\mathrm{n}}(\mathrm{A}), 5.1$ for cytokinin content (B), 3 for root number (C), and 0.6 for turf quality (D). .
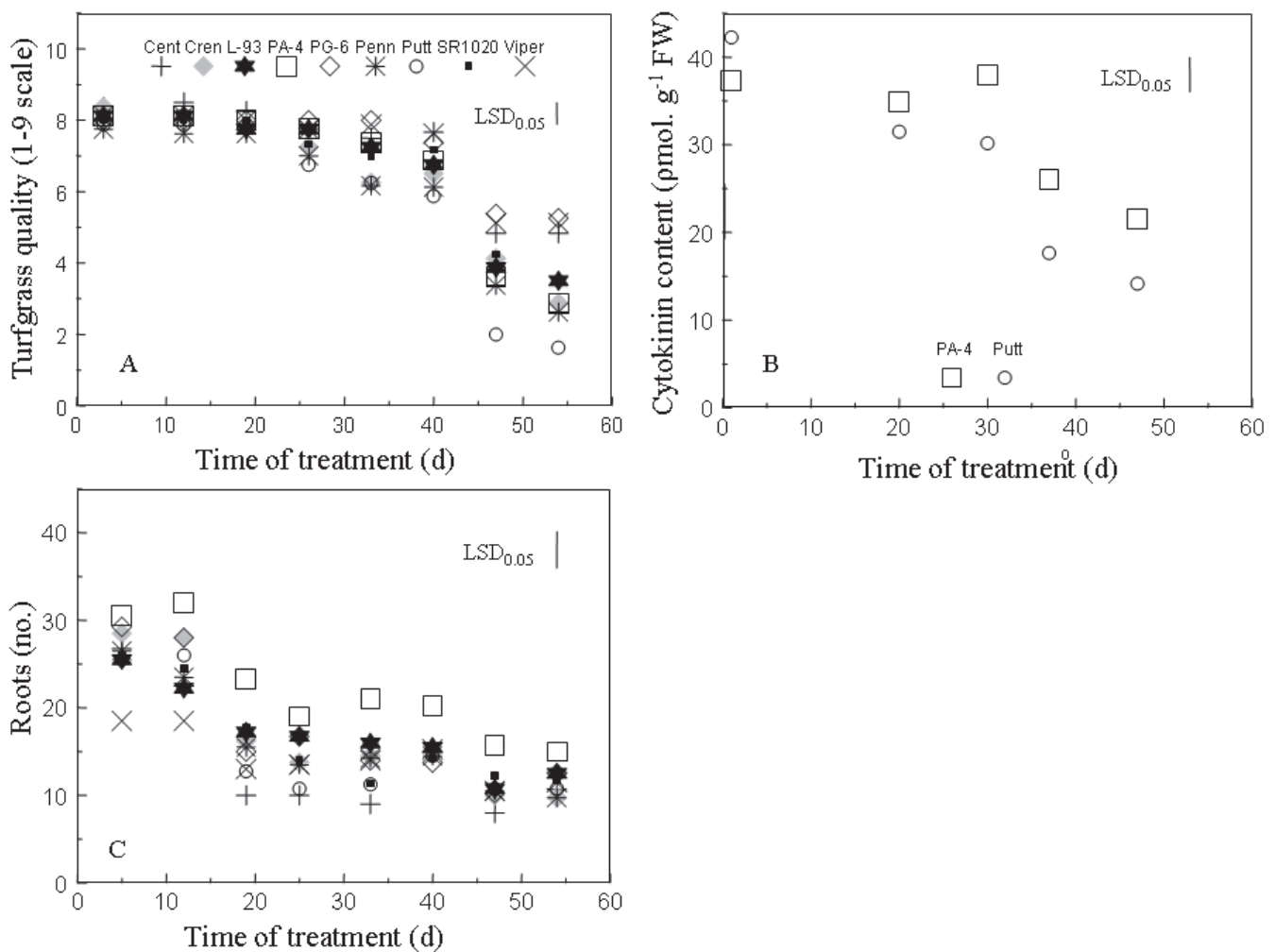

Fig. 8. Changes in turf quality (A), leaf cytokinin content $(\mathbf{B})$, and root number $(\mathbf{C})$ over time at $31^{\circ} \mathrm{C}$ for different creeping bentgrass cultivars. Data were from nine cultivars for root number and turf quality and two cultivars for cytokinin content. Cultivars were 'Century' (Cent), 'Crenshow' (Cren), 'L-93', 'Penn A-4' (PA-4), 'Penn G-6' (PG-6), 'Penncross' (Penn), 'Putter' (Putt), 'SR1020', and 'Viper'. Air temperature was held constant throughout the experiment at $20^{\circ} \mathrm{C}$ for all treatments. Turfgrass quality was rated based on $1-9$ scale, with 9 being the best. The LSD value $(P \leq 0.05)$ for comparison over time of treatment was 0.4 for turf quality (A), 4.2 for cytokinin content (B), and 4 for root number (C). 


\section{Literature Cited}

Al-Khatib, K. and G.M. Paulsen. 1999. High-temperature effects on photosynthetic processes in temperate and tropical cereals. Crop Sci. 39:119-125.

Aloni, B., L. Karni, and J. Daie. 1992. Effect of heat stress on the growth, root sugars, acid invertase and protein profile of pepper seedlings following transplanting. J. Hort. Sci. 67:717-725.

Baret, F., A. Olioso, and J.L. Luciani. 1992. Root biomass fraction as a function of growth degree days in wheat. Plant Soil 140:137-144.

Beard, J.B. 1973. Turfgrass: Science and culture. Prentice-Hall, Englewood Cliffs, N.J.

Beard, J.B. and W.H. Daniel. 1966. Relationship of creeping bentgrass (Agrostis palustris Huds.) root growth to environmental factors in the field. Agron. J. 58:337-339.

Bonos, S. and J. Murphy. 1999. Growth responses and performance of kentucky bluegrass (Poa pratensis L.) under summer stress. Crop Sci. 39:770-774.

Bose, A., B.S. Tiwari, M.K. Chattopadhyay, S. Gupta, and B. Ghosh. 1999. Thermal stress induces differential degradation of Rubisco in heat-sensitive and heat-tolerant rice. Physiol. Plant. 105:89-94.

Caers, M., P. Rudelsheim, H. Van Onckelen, and S. Horemans. 1985.Effect of heat stress on photosynthetic activity and chloroplast ultrastructure in correlation with endogenous cytokinin concentration in maize (Zea mays L.) seedlings. Plant Cell Physiol. 26:47-52.

Crafts-Brandner, S. and M. Salvucci. 2000a. Rubisco activase constrains the photosynthetic potential of leaves at high temperature and $\mathrm{CO}_{2}$. Proc. Natl. Acad. Sci. USA 97:13430-13435.

Crafts-Brandner, S.J. and M.E. Salvucci. 2000b. Rubisco activase constrains the photosynthetic potential of leaves at high temperature and $\mathrm{CO}_{2}$. Proc. Natl. Acad. Sci. 97:13430-13435.

Darrow, R. 1939. Effects of soil temperature, $\mathrm{pH}$, and nitrogen nutrition on the development of Poa pratensis L. Bot. Gaz. (Chicago) 101:109-127.

Downs, C.A., J.S. Coleman, and S.A. Heckathorn. 1999. The chloroplast 22-Ku heat-shock protein: A lumenal protein that associates with the oxygen evolving complex and protects photosystem II during heat stress. J. Plant Physiol. 155:477-487.

Du, Y. and S. Tachinbana. 1994. Effect of supraoptimal root temperature on the growth, root respiration, and sugar content of cucumber plants. Sci. Hort. (Canterbury, Engl.) 58:289-301.

Duff, D.T. and J.B. Beard. 1974. Supraoptimal temperature effects upon Agrostis paulstris : Part II. Infuence on carbohydrate levels, photosynthetic rate, and respiration rate. Physiol. Plant. 32:18-22.

Graves, W., M. Dana, and R. Joly. 1989. Influence of root-zone temperature on growth of Ailanthus altissima (Mill.) Swingle. J. Environ. Hort. 7:79-82.

Gur, A., B. Bravdo, and J. Hepner. 1976. The influence of root temperatures on apple trees. III. The effect on photosynthesis and water balance. J. Hort. Sci. 51:203-210.

Heckathorn, S.A., C.A. Downs, and J.S. Coleman. 1999. Small heat shock proteins protect electron transport in chloroplasts and mitochondria during stress. Amer. Zoologist 39:565-576.

Hoagland, D.R. and D.I. Arnon. 1950. The water-culture method for growing plants without soil. Circ. 347. California Agr. Expt. Sta.

Howard, H. and T. Watschke. 1991. Variable high-temperature tolerance among Kentucky bluegrass cultivars. Agron. J. 83:689-693.

Huang, B. and H. Gao. 2000. Growth and carbohydrate metabolism of creeping bentgrass cultivars in response to increasing temperatures. Crop Sci. 40:1115-1120.

Huang, B. and Q. Xu. 2000. Root growth and nutrient element status of creeping bentgrass cultivars differing in heat tolerance as influenced by supraoptimal shoot and root temperatures. J. Plant Nutr. 23:979-990.

Jiang, Y. and B. Huang. 2000. Effects of drought or heat stress alone and in combination on kentucky bluegrass. Crop Sci. 40:1358-1362.

Knievel, D.P. 1973. Procedure for estimating ratio of live or dead root dry matter in root core samples. Crop Sci. 13:124-126.
Kuroyanagi, T. and G.M. Paulsen. 1985. Mode of high temperature injury to wheat. II. Comparisons of wheat and rice with and without influorescences. Physiol. Plant. 65:203-208.

Kuroyanagi, T. and G.M. Paulsen. 1988. Mediation of high-temperature injury by roots and shoots during reproductive growth of wheat. Plant Cell Environ. 11:517-523.

Law, R.D. and S.J. Crafts-Brandner. 1999. Inhibition and acclimation of photosynthesis to heat stress is closely correlated with activation of Ribulose-1,5-bisphosphate carboxylase/oxygenase. Plant Physiol. 120:173-181.

Li, X., Y. Feng, and L. Boersma. 1994. Partition of photosynthates between shoot and root in spring wheat (Triticum aestivum L.) as a function of soil water potential and root temperature. Plant Soil 164:43-50.

Liu, X. and B. Huang. 2000. Carbohydrate accumulation in relation to heat stress tolerance in two creeping bentgrass cultivars. J. Amer. Soc. Hort. Sci. 125:442-447.

Liu, X. and B. Huang. 2002. Cytokinin effects on creeping bentgrass response to heat stress: I. Leaf senescence and antioxidant metabolism. Crop Sci. 42:466-472.

Liu, X., B. Huang, and G. Banowetz. 2002. Cytokinin effects on creeping bentgrass responses to heat stress: I. Shoot and root growth. Crop Sci. 42:457-465.

Martin, C., D. Ingram, and A. Terril. 1989. Supraoptimal root-zone temperature alters growth and photosynthesis of holly and elm. J. Arboricult. 15:272-276.

Ralston, D.S. and W.H. Daniel. 1972. Effect of temperature and water table depth on the growth of creeping bentgrass roots. Agron. J. 64:709-713.

Salvucci, M., K. Osteryoung, S. Crafts-Brandner, and E. Vierling. 2001. Exceptional sensitivty of rubisco activase to thermal denaturation in vitro and in vivo. Plant Physiol. 127:1053-1064.

Setter, T.L., B.A. Flannigan, and J. Melkonian. 2001. Loss of kernal set due to water deficit and shade in maize: Carbohydrate supplies, abcisic acid, and cytokinins. Crop Sci. 41:1530-1540.

Sharkey, T., M. Badger, M. Caemmerer, and T. von Andrews. 2001. Increased heat sensitivity of photosynthesis in tobacco plants with reduced rubisco activase. Photosynth. Res. 67:147-156.

Todorovic, C., C. Nguyen, C. Robin, and A. Guckert. 1999. ${ }^{14} \mathrm{C}$-assimilate partitioning within white clover plant-soil system: Effects of photoperiod/temperature treatments and defoliation. Eur. J. Agron. $11: 13-21$.

Udomprasert, N., P.H. Li, D.W. Davis, and A.H. Markhart. 1995. Effects of root temperatures on leaf gas exchange and growth at high air temperature in Phaseolus actuitolius and Phaseolus vulgaris. Crop Sci. 35:490-495.

Wang, Z., J. Pote, and B. Huang. 2003. Responses of cytokinins, antioxidant enzymes, and lipid peroxidation in shoots of creeping bentgrass to high root-zone temperatures. J. Amer. Soc. Hort. Sci. 128:648-655.

Watschke, T., R.E. Schmidt, E.W. Carson, and R.E. Blaser. 1973. Temperature influence on the physiology of selected cool season turfgrasses and bermudagrass. Agron. J. 65:591-594.

Weis, E. 1981. Reversible heat-inactivation of the calvin cycle: A possible mechanism of the temperature regulation of photosynthesis. Planta 151:33-39.

Xu, Q. and B. Huang. 2000a. Effects of differential air and soil temperature on carbohydrate metabolism in creeping bentgrass. Crop Sci. 40:1368-1374.

$\mathrm{Xu}$, Q. and B. Huang. 2000b. Growth and physiological responses of creeping bentgrass to changes in air and soil temperatures. Crop Sci. 40:1363-1368.

$\mathrm{Xu}$, Q. and B. Huang. 2001a. Morphological and physiological characteristics associated with heat tolerance in creeping bentgrass. Crop Sci. 41:127-133.

$\mathrm{Xu}, \mathrm{Q}$. and B. Huang. 2001b. Lowering soil temperature improves creeping bentgrass growth under heat stress. Crop Sci. 41:1878-1883.

$\mathrm{Xu}, \mathrm{Q}$., B. Huang, and J. Fry. 2000. Seasonal changes in shoot and root growth and carbohydrate metabolism of creeping bentgrass. U.S. Golf Assn., Far Hills, N.J. 